\title{
Pojęcie duchowości w tradycji polskiej, świeckiej myśli pedagogicznej
}

\begin{abstract}
Abstrakt
Artykuł przedstawia bogactwo znaczeń związanych z pojęciem duchowości. Zaprezentowano w nim kilka charakterystycznych definicji, które poddano krytycznej analizie w kontekście pedagogiki kultury B. Nawroczyńskiego. Duchowość analizowana w perspektywie świeckiej, naukowej wydaje się nie tylko bardziej uniwersalna, ale także wolna od ograniczeń, jakie pociągają za sobą ujęcia teonomiczne. Najszerszym pojęciem duchowości jest pojęcie wspólnoty duchowej, które otwarte jest na wielość treści i form, które mogą ją wypełnić.
\end{abstract}

Słowa kluczowe: pedagogika, filozofia wychowania, duchowość, Nawroczyński.

\section{The Concept of Spirituality in the Tradition of Polish Secular Pedagogical Thought}

\begin{abstract}
The article presents the variety of meanings associated with the concept of spirituality. It shows several characteristic definitions, which have been critically analysed in the context of Nawroczyński's pedagogy of culture. Spirituality analysed from a secular, scientific perspective seems not only more universal, but also free from the limitations of theonomic approaches. The broadest concept of spirituality is the concept of spiritual community, which is open to the multitude of content and forms that can fill it.
\end{abstract}

Keywords: pedagogy, philosophy of education, spirituality, Nawroczyński.

\footnotetext{
* Akademia Techniczno-Humanistyczna w Bielsku-Białej. Artykuł otrzymano: 30.11.2020; akceptacja: 12.01.2021.
} 
W kulturze śródziemnomorskiej należy poszukiwać korzeni duchowości w pierwszych koncepcjach filozoficznych m.in. u Pitagorasa, Platona, Arystotelesa. Te pierwotne koncepcje duszy zakładały jej wewnętrzną hierarchię i tylko najwyższe jej części były odnoszone do istoty myślącej, jaką jest człowiek. Zatem pierwsze koncepcje duszy utożsamiały duchowość z rozumnością, a duszę rozumną czyniły odpowiedzialną za człowieczeństwo. Niższe części duszy podległe duszy rozumnej - dusza zwierzęca czy roślinna - dotyczyły całego pozostałego biosu. Zatem problem duchowości zakładał dualistyczną antropologię, tzn. człowiek łączył w sobie po pierwsze pierwiastki zwierzęce jak i ponadzwierzęce oraz po wtóre powiązanie sfery duchowej ze sferą noetyczną (nous - rozum). Konsekwentnie wynikało z tego, że tylko byty obdarzone zdolnością myślenia są uprawnione do tego, aby postrzegać siebie jako istoty duchowe. Stanowisko Pitagorasa i Platona z jednej strony oraz Arystotelesa z drugiej strony różniły się między sobą, prowadząc do specyficznych konsekwencji na gruncie antropologii, a następnie w refleksji wychowawczej. Dwaj pierwsi postrzegali życie duchowe jako ekspresję doskonałych idei obecnych w podmiocie, a samą duszę jako nieśmiertelną, gdy tymczasem Arystoteles nie podjął problemu nieśmiertelności duszy, natomiast swoją koncepcją tabula rasa dał podstawę nie tyle odkrywaniu duchowości w człowieku, co jej budowaniu w trakcie życia.

Zakotwiczenie duchowości w świecie inteligibilnym prowadzi do kolejnego rozróżnienia, mianowicie duchowe jest to, co niematerialne, poza/ponadzmysłowe. I tej niematerialnej duchowości przypisano wieczne trwanie. Wszystko co żyje, poza człowiekiem ma swój materialny kres, natomiast „wynalezienie” nieśmiertelnej duszy nadawało człowiekowi, a jeszcze bardziej abstrakcyjnej kategorii człowieczeństwa zupełnie nową jakość. Powiązanie tego z kreacjonizmem, z doskonałym bogiem było już tylko logicznym domknięciem marzenia człowieka o uniwersalności.

Problem tego, co nazywamy duchowością, jest od dawien dawna otwarty choćby z tego powodu, że pojęcie to jest głęboko nieostre, a jego redukcja do takiej czy innej religii wyklucza cały szereg zjawisk, które leżą poza ich wyobrażeniami. Uderzające jest to, jak pojęcie duchowości zostało jednostronnie zawłaszczone przez religie, niemal sugerując, że nie może ono mieć innych niż religijne konotacji ${ }^{1}$. Świadczy o tym błędne w swej istocie przekonanie, aby wiedza pedagogiczna - tak wrażliwa na duchowość człowieka - była poza filozofią włączana do teologii moralnej szczegółowej². Oznaczałoby to, że pedagogika z tego punktu widzenia

\footnotetext{
1 Dusza to „forma ciała, dzięki czemu stanowi jeden byt substancjalny, osoba zatem składa się i z duszy i z ciała", a ta jest niematerialna (por. Krąpiec 1991: 37). Wojciech Chudy proponuje bardziej noologiczną wykładnię. „Jako substancja człowiek jest jednością materialno-duchową, jest jednością złożoną z ciała i duszy, w której dusza jest swoistą formą scalającą, doskonalącą i dopełniającą człowieka. Tą formą substancjalną (...) jest intelekt ludzki, umysł, który przejawia się w człowieku jak gdyby w dwóch wersjach: w postaci rozumu i woli" (Chudy 1996: 142; Leszczyński 2021: 40).

2 „Nie można mówić o realistycznej pedagogii osoby bez uwzględnienia jej duchowości i wychowania religijnego będącego prostą jej konsekwencją" (Sztaba 2015: 41, 43). Z pewnością nie jest kontralter-
} 
stała się integralną częścią teologii, a jedynym wymiarem duchowości byłoby zwrócenie się człowieka w stronę transcendencji, bóstwa, ku jakimś subiektywnym doświadczeniom związanym ze światem nadprzyrodzonym. Jednak z naukowego punktu widzenia ta sfera nie może być objęta badaniami, które spełniałyby kryteria naukowości³ . Jeśli WHO definiuje duchowość jako wewnętrzne zasoby człowieka, to $\mathrm{z}$ tej bardzo szerokiej i nieostrej wykładni nie wynika bezwyjątkowe powiązanie duchowości ze sferą religii. Duchowość i jej brak nie jest też rozpięta między religijnością i sekularyzacją, wszystko bowiem zależy od tego, co przez to pojęcie rozumiemy. Dość oczywiste są ideologiczne przekonania poszczególnych wyznań, że kwestie duchowe są powiązane dokładnie z ich religiami, tymczasem to pojęcie nie musi być redukowane do orientowania życia ludzi wokół takiej czy innej wersji transcendencji. Życie duchowe może oznaczać pogłębioną więź z szeroko rozumianą kulturą, z kultywowaniem wartości, które czynią ludzkie życie sensownym i głębokim, mądrym, dobrym, pięknym i sprawiedliwym. Zatem życie duchowe będzie także tworzeniem dotąd nieistniejących dóbr, które będą punktem wyjścia dla twórczej obecności kolejnych pokoleń.

Punktem wyjścia dalszej analizy niech będzie przywołanie desygnatów tego pojęcia, które w wersji słownikowej zawiera bardzo bogatą listę konotacji. Zwrócę tylko uwagę na niektóre, które są najbliższe językowi potocznemu. Duchowość zatem może dotyczyć sposobu myślenia, ale i fantasmagorii, może się wyrażać w mitach, rytuałach, w odkrywaniu głębokich pokładów ludzkiej refleksji, ale i intuicji, może być wyrazem ludzkiej natury w kontrze do bytu materialnego, może oznaczać nasze usposobienie, postawę moralną, wzniosłość, energię do pracy czy walki lub - w wersji negatywnej - brak głębszych pokładów. Duchowość jest jednocześnie stanem i przemianą. Jest równocześnie źródłem i skutkiem ludzkiej wolności. Czasem, szczególnie w poezji, jest związana z aurą miejsca, czasu, wydarzenia, ludzi.

W sensie semantycznym pojęcie to $\mathrm{z}$ racji bogactwa znaczeń może odgrywać pozytywną rolę w codziennej komunikacji, wyrażając subtelne stany i nastroje, natomiast w nauce jego wieloznaczność może być źródłem nieporozumień, uproszczeń i redukcji. Jak wielkie są trudności z jej zdefiniowaniem niech świadczy próba jej dookreślenia podjęta przez Pawła M. Sochę. Zaproponował on dwie wykładnie o różnym stopniu ogólności. Pierwsza - szczegółowa - mówi, że „duchowość człowieka to zjawisko wykorzystujące wrodzone i nabyte zasoby w celu radzenia sobie z sytuacjami egzystencjalnymi”, druga - ogólna głosi, że „duchowość to wszelkie działania zmierzające do pokonania (przekroczenia, transcendencji)

\footnotetext{
natywą duchowości „żywiołowa witalność i seksualność”, jak twierdzi M. Sztaba, podobnie jak nie jest podważeniem religijności jako takiej pedofilia księży.

3 Do pewnego stopnia dylematy z kategorią duchowości w psychologii o proweniencji empirycznej omawia P. Socha (tenże 2014: 9-22). Stawia on tezę, że psychologia akademicka, mając świadomość trudności tematu, uznaje go „za wstydliwy”, choć w innym miejscu komentując przegląd statystycznego rozwoju publikacji na ten temat wyraźnie podkreśla jego wykładniczy charakter (tamże: 11).
} 
granic własnej egzystencji oraz ich rezultaty" (Socha 2014: 13). Pierwsza definicja bardziej wyjaśnia pojęcie rozwoju człowieka, który dokonuje się w bio-socjo-kulturowym kontekście. Aby radzić sobie z sytuacjami egzystencjalnymi, nie trzeba odwoływać się do pojęcia duchowości. Zwierzęta także dzięki wrodzonym i nabytym zasobom rozwiązują wszystkie problemy, jakie napotykają w swoim ekosystemie. Gubi się też pierwotna intuicja duchowości, jaką znajdziemy u Arystotelesa, wyodrębniająca człowieka za pomocą tego pojęcia z całego biosu. Jeśli na chwilę pozostaniemy przy stanowisku Stagiryty, to z konieczności musimy wskazać takie środowisko, które nie jest wspólne dla ludzi i nazwijmy to umownie - zwierząt. Tym środowiskiem jest kultura i z nią w konsekwencji możemy wiązać pojęcie duchowości. Zatem pierwsza definicja wydaje się nietrafna. Problem z drugą wykładnią jest innego rodzaju. Bez wątpienia tym, co w duchowości rzuca się nam w oczy, jest jej sprawczy charakter, człowiek, np. artysta, jest postrzegany jako istota uduchowiona, ponieważ w jego wytworach dostrzegamy zmaterializowane postaci ekspresji jego twórczości, którą uznajemy za jeden z aspektów konotujących duchowość w ogóle. Bycie człowiekiem uduchowionym jednak nie musi być równoznaczne z działaniem. To także pewien stan opisujący człowieka jako całość, którego zasadniczym atrybutem jest posiadanie głęboko zinterioryzowanego systemu wartości. I w żadnym wypadku nie możemy zredukować tych wartości do wartości wyznawanych w pewnej arbitralnie przyjętej grupie społecznej czy wyznaniowej. Wskutek tego z pojęciem duchowości będziemy wiązać pewien zbiór wartości oraz ich ponadczasowe i ponadprzestrzenne obowiązywanie ${ }^{4}$. Psychologowie, abstrahując od badań „humanistów” (ten zapis może oznaczać dystansowanie się części psychologów od ich opisów), wiążą to pojęcie ze świadomością badanych, ich postawami, potrzebami, transgresją, progresem i regresem. Duchowość $\mathrm{w}$ tej konwencji badawczej jest postrzegana realistycznie (daje się zoperacjonalizować), ale w konsekwencji jest zredukowana do jakiejś mniej lub bardziej fragmentarycznej postaci psychologii osobowości. Diagnostyczny charakter psychologii empirycznej (np. Inwentarz Wrażliwości Duchowej) wydaje się niewystarczający do uchwycenia istoty tego zjawiska. Badania empiryczne obciążone niemożnością w pełni enumeracyjnych analiz świadomości respondentów, a także quasi-socjologiczne charakterystyki „potocznej fenomenologii” wykazują już na poziomie założeń metodologicznych zasadniczą trudność. Pytamy bowiem albo o to, co myślą wybrane jednostki, zatem wynik takich badań czy nawet ukuta na tej podstawie teoria nie będą miały szerszego niż ta grupa zasięgu, albo odwołamy się

\footnotetext{
${ }^{4}$ Do takiego stanowiska skłania się M. Straś-Romanowska, twierdząc, że „duchowość wiąże się z akceptacją i realizacją uniwersalnych, ponadczasowych wartości, nadawaniem sensu życiu" (cyt. za: Kapała 2017: 9). Autorka przytacza szereg wykładni pojęcia duchowości, w których jest ona m.in. potrzebą odkrywania sensu życia, transcendentnym wymiarem doświadczenia, spoiwem osobowości, fenomenem przenikającym wszystkie obszary ludzkiej egzystencji, warunkiem dobrostanu. Wielość tych koncepcji świadczy o tym, że to pojęcie na przestrzeni długiej historii myśli ludzkiej jest nasycone ogromnym bogactwem znaczeniowym.

5 Taką formułę w swoim artykule przyjął P. Socha.
} 
do potocznych interpretacji duchowości, które obciążone będą poza ograniczonym społecznym zasięgiem dodatkowo subiektywizmem oraz nieuświadomionymi przedzałożeniami. Poza tym błąd może tkwić również w liniowym podejściu do badań duchowości - jeśli za Z. Pietrasińskim - uznamy duchowość za rezultat autokreacji. Relacja wydaje się być zwrotna, to znaczy także autokreacja bez duchowości nie wydaje się możliwa.

W pedagogice XX w., szczególnie w pierwszej połowie tego stulecia, w ramach filozoficznie ukonstytuowanej pedagogiki kultury pojęcie duchowości było powiązane ze sferą wartości kultury, których najpierw głęboka interioryzacja, a następnie ekspresja miały świadczyć o osobowości dojrzałej, pełnej. Kultura była w tej perspektywie niczym innym jak sanktuarium duchowości, a dbałość o człowieczeństwo możliwą dla każdego indywidualnie szansą na osiągnięcie jej pełni i tym samym ekspresją życia duchowego. Dlatego nie jest niezbędne transcendowanie wartości do irrealnych bytów boskich, aby uznać człowieka za istotę duchową, o ile chcemy jeszcze posługiwać się tym nieostrym terminem. Świadomość wieloznaczności tego pojęcia miał również Bogdan Nawroczyński, autor dzieła Życie duchowe. Zarys filozofii kultury, które z racji swego podejścia do tematu nie traci swego znaczenia pomimo upływu blisko 80 lat. $\mathrm{Z}$ jego punktu widzenia pojęcie to jest „mętne i nieustalone”. Prekursora w Polsce w badaniach nad życiem duchowym dostrzegał w wybitnym psychologu Janie Władysławie Dawidzie, który po przełomie wywołanym tragedią rodzinną zwrócił się ku tej problematyce. Nie bez kozery zwracam uwagę na jednego $\mathrm{z}$ czołowych przedstawicieli polskiej psychologii empirycznej, ponieważ współczesne psychologiczne badania go nie dostrzegają. Jednak o ile stanowisko Nawroczyńskiego jest wolne od konotacji religijnych, to punkt widzenia Dawida niestety nie. Przejście od opisu życia duchowego, uchwycenia jego pełnego sensu do poszukiwania związków ze światem transcendentalnym nie jest charakterystyczne wyłącznie dla Dawida. Osobiste nieszczęście w tym kierunku pchnęło także Witolda Rubczyńskiego, do którego także odwoływał się Nawroczyński ${ }^{6}$. Z psychologicznego punktu widzenia jest zrozumiałe, że utrata bliskich może zmodyfikować czy ukierunkować myślenie ku jakiemuś uniwersum, dzięki któremu możemy odtworzyć czy kontynuować utraconą z nimi jedność, więź. Nawroczyńskiemu jednak chodziło o coś innego - o wydobycie takiego znaczenia pojęcia duchowości, które połączyłoby byt indywidualny z ponadindywidualnym i obiektywną rzeczywistością, w której te byty osiągają swoją jednię. $\mathrm{W}$ jego wykładni to pojęcie otrzymało następującą konotację jako: „poryw ku światu ideałów, które budzą się na tle wzmożonej uczuciowości” (Nawroczyński 1947: 20). Zgodnie z poheglowskim podziałem na ducha subiektywnego, obiektyw-

\footnotetext{
6 W. Rubczyński, charakteryzując duchowość, twierdził, że „Dobra duchowe, jak prawość charakteru, ścisłość i rozległość umysłu, muszą dobić się uznania, iż są cenniejszemi od dóbr materjalnych, że nie podlegają zniszczeniu przez fizyczną przemoc, chorobę, ani śmierć" (Rubczyński 1925: 2). Pogląd ten jest obecny w kulturze europejskiej od VI/V w. p.n.e. w słynnym powiedzeniu filozofa greckiego Biasa z Prieny, przyswojonym kulturze w wersji łacińskiej omnia mea mecum porto.
} 
nego i zobiektywizowanego, w tej wykładni ducha łączą się ze sobą wszystkie wymienione jego sfery. Nawroczyński doprecyzował, co w filozofii wychowania XX w. oznaczają te terminy. Duch subiektywny oznaczał dla niego tę część życia wewnętrznego człowieka, która dotyczyłaby związków podmiotu z kulturą, duch obiektywny obejmowałby całokształt życia społecznego konstytuującego się w tyglu historii, zaś wytwory kulturalne za Nicolai Hartmannem nazywał duchem zobiektywizowanym. Takie dookreślenie sfery ducha otworzyło przestrzeń do naukowych badań nad nią bez konieczności odwoływania się do bytów transcendentalnych, mitów itp. ${ }^{7}$ Charakterystyczną tezą Nawroczyńskiego było również przekonanie, że życie duchowe nie jest tożsame z życiem psychicznym. Podkreślam tę tezę, ponieważ w badaniach psychologów taka redukcja ma miejsce ${ }^{8}$. Oznacza to, że z perspektywy stanowiska Nawroczyńskiego psychologowie nie do końca trafnie nazywają wytwory swoich badań w tym zakresie. Tym natomiast, co łączy prezentowane tu historyczne stanowisko ze współczesnymi badaniami jest docenienie - w definiowaniu tego terminu - jego czynnościowego, twórczego charakteru. Ostatecznie propozycja Nawroczyńskiego zmierzała do zdefiniowania ducha jako: „żywej, zdrowej i twórczej kultury, oglądanej od strony celów ludzkich. A życie duchowe jest dla nas życiem tak pojętej kultury" (Nawroczyński 1947: 23). Wydaje się, że ta koncepcja - szczególnie w badaniach pedagogicznych - ma wyjątkowe walory. Taka optyka przede wszystkim nie izoluje człowieka od szerokiego kontekstu naturalnego, społecznego, kulturowego. Człowiek postrzegany jako istota duchowa jest bytem ingerującym w ten szeroki kontekst, ale i zarazem będącym jego wytworem. Jest bierny i czynny jednocześnie. Duchowość oznacza równoczesność pewnej formy aktywności nastawionej na realizację celów wartościowych (a więc działania przeciwne, choćby najbardziej genialne, takiego atrybutu nie posiadają) z pewnym wewnętrznym stanem, który tę aktywność umożliwia. Ten zwrotny charakter duchowości wydaje się jednym z zasadniczych jej wymiarów. Reasumując - poza kulturą, przynajmniej w świeckiej koncepcji Nawroczyńskiego, duchowość nie jest możliwa. Po wtóre, zgodnie z brzytwą Ockhama nie są wprowadzane żadne dodatkowe byty, dzięki którym można adekwatnie się wypowiadać o podmiotowej i przedmiotowej stronie duchowości, po trzecie, taka koncepcja ma istotne walory służące pedagogii, której istotnym zadaniem jest - znów przywołując niezwykle trafny termin Nawroczyńskiego - telehormizm oraz enkulturacja człowieka. Przez odniesienie duchowości do kultury, której atrybutem jest trwanie w czasie, zaspokojona jest pedagogicznie ważna ludzka potrzeba tożsamości. Może ona być konstruowana na bazie uznanych wartości, które niesie określona tradycja, ale i na bazie kreowanych wartości, które są wyrazem twórczej/transgresyjnej

\footnotetext{
7 Nawroczyński uważał, że do charakterystyki celów ludzkich „odpowiedniejszy jest termin duch, oczywiście po oczyszczeniu go z wszelkich prymitywnych, metafizycznych i mistycznych znaczeń" (Nawroczyński 1947: 22).

8 Psychologowie, posiłkując się badaniami światowymi, albo nie znają, albo ignorują rodzimą twórczość w tym zakresie.
} 
aktywności człowieka. Mamy tu także pewną klamrę spinającą pierwsze, antyczne koncepcje z badaniami współczesnymi - tak pojęte życie duchowe decyduje o naszym człowieczeństwie, zatem o doskonałości moralnej, intelektualnej czy estetycznej. XX-wieczny telehormizm odpowiada na walor wartości odkrytych w starożytności i tak jak wówczas kieruje człowieka ku granicom jego możliwości. Podążając tym tropem, dochodzimy do przekonania, że życie duchowe człowieka wyznaczają wartości (żywe i ożywcze) mieszczące się w kulturze. W związku z tym możliwa jest następująca gradacja „zanurzania się” w kulturze - duchowość postrzegana jako partycypacja w systemie wartości, której następstwem jest duchowość odnosząca się do zmierzania i stopniowego osiągania doskonałości przez człowieka, aż wreszcie na najwyższym poziomie osiągana może być jedność w różnorodności na poziomie wspólnoty duchowej ${ }^{9}$. Zauważmy, że ten sposób myślenia o duchowości zawiera, jako swój immanentny składnik, uznanie dla różnorodności oraz szacunek dla każdego podmiotu. Ta wielość nikogo także nie wyklucza, każdy bowiem na swój sposób i na miarę swoich możliwości może zmierzać ku tej wspólnocie. Duchowość rozumiana w kontekście wyznaniowym jest oczywiście możliwa, jednak trzeba mieć świadomość tego, że teologia jest jedynie częścią tej kultury, a nie jej całością. Zatem zawłaszczenie tego pojęcia przez takie czy inne wyznania w świetle świeckiej koncepcji Nawroczyńskiego nie wydaje się uprawnione, a jednocześnie jest zagrożone swoistym elitaryzmem i wykluczeniem tych, którzy się poza nim znajdują. W globalnej wiosce powinniśmy raczej szukać dróg prowadzących do wspólnoty duchowej, która będzie maksymalnie otwarta dla wszystkich, bez względu na lokalnie dzielące nas różnice ${ }^{10}$. Ludzkość i człowieczeństwo w tej perspektywie nie są pustymi słowami.

\section{Bibliografia}

Chudy W. (1996) Prawda człowieka i prawda o człowieku w: Człowiek - wartości - sens. Studia z psychologii egzystencjalnej (Logoteoria i nooteoria, Logoterapia i nooterapia), red. K. Popielski, Lublin, Redakcja Wydawnictw Katolickiego Uniwersytetu Lubelskiego, s. 129-148.

Kapała M. (2017) Duchowość jako niedoceniany aspekt psyche. Propozycja nowego ujęcia duchowości w psychologii - kategoria wrażliwości duchowej, „Annales Universitatis Mariae Curie-Skłodowska", Sectio J, vol. XXX, Lublin, s. 7-37.

\footnotetext{
${ }^{9}$ Dzisiaj pojęcie wspólnoty duchowej zniknęło z kart pedagogicznych tekstów naukowych, ale w okresie międzywojennym było jednym ze źródeł radykalnej zmiany w pedagogice. Przykładem może być stanowisko P. Petersena, który interpretował wychowanie jako pierwotną funkcję ducha doskonalącą się w rozrastających się wspólnotach - rodziny, narodu i ludzkości.

${ }^{10} \mathrm{~W}$ tym zakresie jednoznacznie wyrażał swój pogląd twórca etyki niezależnej T. Kotarbiński. Pisał bowiem tak: „Jednakże uczciwe, prawe, przyzwoite, zdyscyplinowane, zgodne z sumieniem życie nie potrzebuje uzasadnienia w religii, metafizyce. Zanim ludzkość nauczy się niebiańskiego uśmiechu, musi się wprzódy oduczyć szczerzenia zębów" (cyt. za: Mróz 2008: 153).
} 
Krąpiec M. A. (1991) Ja-człowiek, Lublin, Redakcja Wydawnictw Katolickiego Uniwersytetu Lubelskiego.

Leszczyński S. (2021) Pedagogiczne aspekty personalizmu Wojciecha Chudego, Łódź, Wydawnictwo Naukowe Towarzystwa Pedagogiki Filozoficznej „Chowanna”.

Mróz T. (2008) Kotarbiński postawiony do kąta, „Pro Libris. Lubuskie pismo literacko-kulturalne", nr 2.

Nawroczyński B. (1947) Życie duchowe. Zarys filozofii kultury, Kraków-Warszawa, Księgarnia Wydawnicza F. Pieczątkowski i S-ka.

Rubczyński W. (1925) Filozofia życia duchowego, jego wytrzymałość, skuteczność i ład w świetle doświadczenia i krytyki, Poznań, Fiszer i Majewski.

Socha P. (2014) Przemiana duchowa jako kluczowe pojęcie psychologii rozwoju człowieka, „Psychologia Rozwojowa”, t. 19, s. 9-22.

Sztaba M. (2015) Pedagogia osoby wobec zagadnienia duchowości, „Forum Pedagogiczne", nr 2, s. 41-62. 